\title{
KRITIK IDEOLOGI ATAS GERAKAN ANTI HAK ASASI MANUSIA DI INDONESIA
}

\author{
Usman \\ Tarbiyah UIN Sunan Kalijaga Yogyakarta \\ Email: usmanmbabsel@gmail.com
}

\section{Abstract}

Step Real Counterat Communist Movement that contrast to Human Right through Education: $A$ Critique Ideology. This discussion describes the emantipatory critical social theory of Jürgen Habermas antithesis to the ideology of Marxist-Leninist-Maoist-Communist Party. It Explained that the concept of rationalization of community development; emancipatory form of social interaction, bas proceeded in a fair and balanced. Include: the rationalization of technical/job dimensions, rationalization of practice/dimensions of interaction or communication, and rationalization of the system/power dimension. By this, they can expand the tecbnical mastery of the extemal world, capable of conditioning the situation of buman communication that is free as well, and may set technical goals and practice themselves perfectly. This is the development of community/buman to fit bis (buman), witbout getting stuck in ideology. While the Marxist-Leninist-Maoist-Communist Party, stuck into a one-sided rationalization, ie technical/instrumental action, so that people/ bumans evolved in shades of rational action aims/production (reification of self; mechanical, linear, scientistic, and indoctrination (ideological), because there is no interaction and communication. His idea can be implemented througb bis educational concept. First, buman beings should lead to the acbievement of buman beings capable of managing the world with shades of deep understanding (Bermeneutics and Versteben) the reality of bis next life, as well as in dialogical relations system; equivalent, communicative, and egalitarian. Second, it must be supported by a curriculum that be able to nurture the potential of cognitive interests: technical, practice and emancipatory. Third, it must be realized by the method of leaming with the theoritic and pratical model.

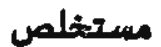

منع ربال ملربل من خلال التعليم الخطوة الثيوعية بغيرانسانية: نقل أيليولوجية. هذه

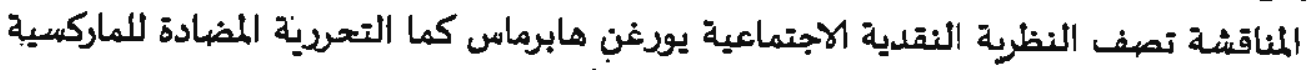


لينينية الماويين- الأيديولوجية. المشيوعية الاندنسي. وأوضيح أن مفهوم ترشيل تنمية المجتمع؛

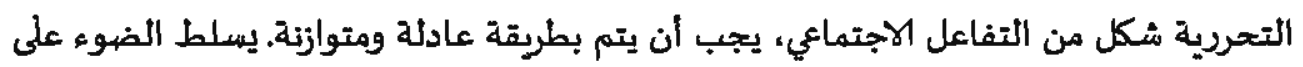

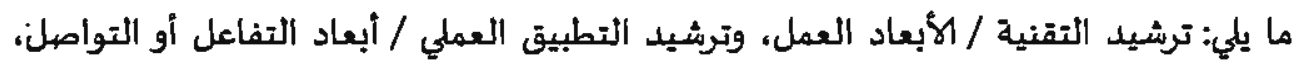

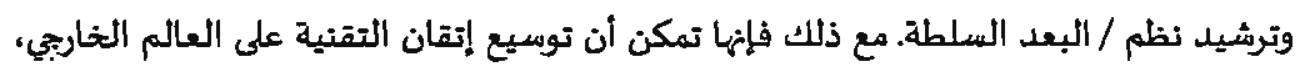

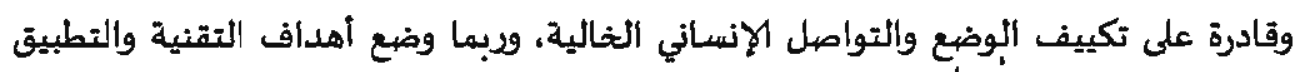

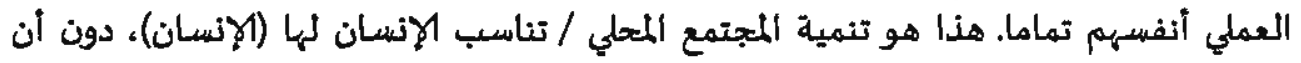

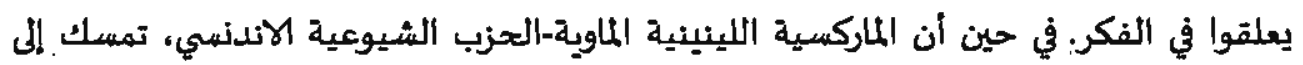

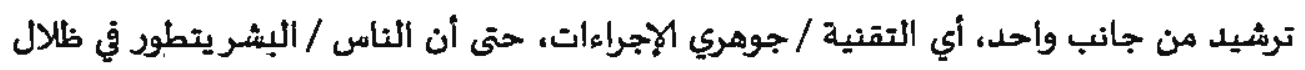

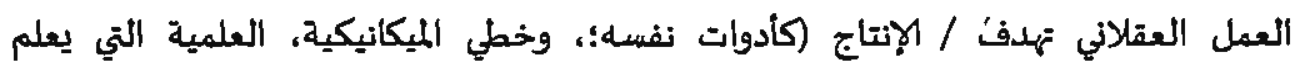

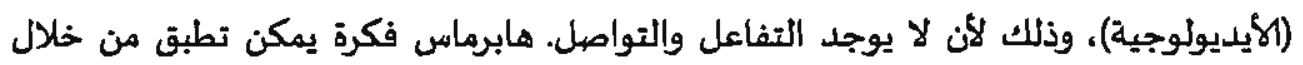

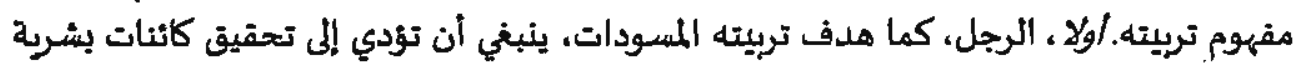

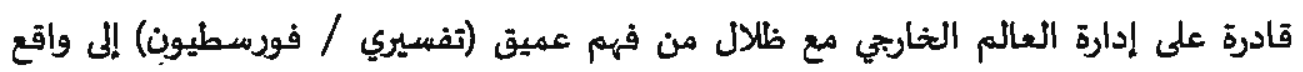

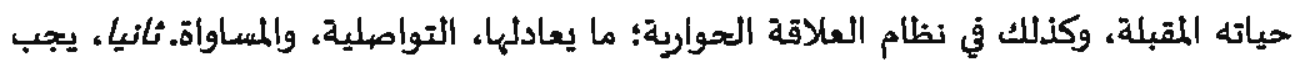

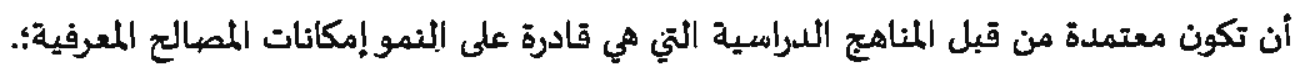

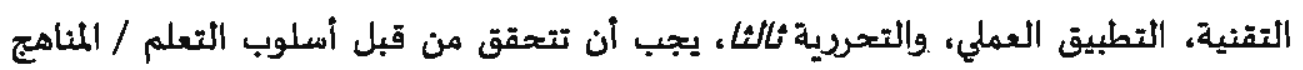

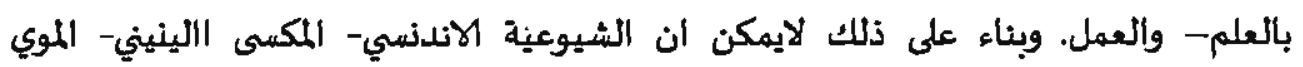
النموذجى.

Keywords: Ideologi, Anti Hak Asasi, Indonesia, Komunis, Pendidikan.

\section{A. Pendahuluan}

Idiologi Komunisme-Atheisme-Marxisme ortodoks, masuk ke Indonesia sejak zaman Belanda lewat tokohnya Hendrik Sneevliet (dikenal dengan Marin) dan mendirikan ISDV (Indische Sociaal Democratische Vereneging), di Surabaya tahun 1914. ${ }^{1}$ Untuk membesarkan organisasi itu, para tokohnya seperti Tan Malaka, Semaun, Muso, Darsono dan Alimin, masuk ke partai dan organisasi yang maju

${ }^{1}$ John D. Legge, Soekamo: Sebuab Biografi Politie, terj: 'Tim PSH., Jakarta: Sinar Harapan, 1985) hal. 69. 
saat itu seperti Sarekat Islam (juga Budhi Utomo, dll.). Tujuannya ialah menjadikan partai dan organisasi itu sebagai kendaraan untuk menyampaikan aspirasinya yang radikal. ${ }^{2}$ Cara tersebut bisa terjadi sebab partai dan organisasi pada waktu itu jarang menerapkan aturan yang ketat untuk melarang anggotanya berpartai/berorganisasi ganda. Namun karena melihat tidak adanya manfaat untuk menerima kelompok minoritas radikal (ISDV) tersebut, maka kelompok konservatif S.I memaksa kelompok ISDV keluar. Kondisi inilah yang menjadikan ISDV merombak dirinya menjadi Partai Komunis Indonesia pada Mei 1920. ${ }^{3}$

Sejak keluar dari S.I, PKI semakin radikal, terutama setelah pertemuan para pemimpin mereka pada Desember 1925 di Prambanan. ${ }^{4}$ Pertemuan itu memutuskan bahwa PKI harus melakukan tindakan yang lebih radikal dan terbuka. Maka pemberontakan I dimulai pada November 1926 di dua daerah; Jawa Barat dan Sumatera Barat, serta dibarengi dengan pengumuman terbentuknya sebuah Republik. Tentu saja ini dihancurkan oleh kolonial Belanda dan pada 1927 PKI dinyatakan terlarang. Namun mereka tetap bergerak meski di bawah tanah. ${ }^{5}$

Setelah gagal tahun 1926, selaku tokoh PKI yang dibuang Belanda, Muso pulang dari Moskwa tahun 1935 untuk menyusun kekuatan baru. Akan tetapi ia tinggal hanya sebentar di tanaki air, dan kemudian PKI bergerak dalam berbagai organisasi, seperti Gerindo dan serikat-serikat buruh. Tahun 1948, PKI melakukan lagi pemberontakan di Madiun, dengan tokohnya Semaun, Darsono dan Alimin. Alasannya ialah tidak terakomodasinya secara mayoritas tokoh PKI dalam Kabinet Presidentil yang dibentuk Soekarno, setelah bubarnya kabinet Syarifuddin dan pindahnya Ibu kota ke Yogyakarta, serta terjadinya agresi Belanda kedua pada 1948. Dalam kondisi kacau itulah PKI mengambil

\footnotetext{
2 Ibid.

${ }^{3}$ Ibid, hal. 77 .

${ }^{4}$ Ibid, hal.104-105.

${ }^{5}$ Anonym. dikutip dari http:// wikimediafoundation,org// diunduh 18 April 2012.

${ }^{6}$ John D. Legge, Soekamo: Sebuab Biografi Politik,... hal. 262-263.
} 
kesempatan untuk menggulingkan pemerintahan yang sah. Akan tetapi hal itu dapat ditumpas oleh pemerintah Indonesia.

Petkembangan berikutnya PKI masih mampu mengkonsolidasi kekuatannya. Ini terbukti dengan tetap eksisnya di bumi Indonesia, bahkan pada Era Orde Lama terjadi hubungan yang erat dengan Presiden Soekanno. PKI melakukan infiltrasi ke semua instansi negara, terutama militer. ${ }^{7}$ Puncak hubungan PKI dengan pemerintahan Soekarno ialah demi cita-cita idiologi masing-masing. Soekarno demi Marhaenismenya dan PKI demi MarxisLeninisme-Maoisme. Kemudian keduanya muncul dalam langkah politik berupa retuling terhadap DPR, yang cukup hanya diwakili oleh tiga partai: Nasionalis-Agama-Komunis/NASAKOM. ${ }^{8}$ Peluang besar itu dimanfaatkan PKI untuk melakukan pemberontakan, yang kemudian dikenal dengan G $30 \mathrm{~S}$. PKI.

Tampaknya idiologi di atas tidak diterima secara luas oleh masyarakat Indonesia. Ini ditandai dengan gerakan penumpasan G $30 \mathrm{~S}$. PKI. yang dikomandani militer dan dipimpin oleh Mayor Jenderal Soeharto. Tindakan keji PKI sangat membekas pada masyarakat dan membikin trauma mereka. Oleh karena itu masyarakat, dengan TRITURANYA, bersama pemerintah dengan tegas minta dibubarkannya PKI di Indonesia ${ }^{10}$ Meskipun sudah ditumpas habis dan dilakukan pembinaan mendasar dengan idiologi Pancasila, tetapi dipastikan bahwa idiologi komunis masih ada di Indonesia dan diusahakan untuk dikembangkan kembali, walaupun dalam bentuk gerakan bawah tanah. Ini ditegaskan oleh kantor berita Tass (Uni Soviet) tahun 1969 setelah berlangsung Konggres Partai Komunis Sedunia. ${ }^{11}$

${ }^{7}$ A.H, Nasution, Memerwbi Pangilan Tugas: Jilid 5 Kenangan Orde Lama, Jakarta: CV. Haji Masagung, 1989), hal, $30-31$.

${ }^{8}$ Ibid, hal. 6-7.

${ }^{9}$ Soegiarto, Soerojo, Sicpa Menabur Angin Akan Menuai Badai: G 30 S PKI dan Peran Bung Kanto, (Jakarta: Intermasa, 1988), hal. 388-389.

${ }^{10}$ Ibid, hal. 239-258.

11 Ibid, hal. 351. 
Selain itu memang sebagian besar kaum komunis cenderung mengikuti teori Revolusi Permanennya Leon Trotsky. ${ }^{12}$ Kemudian sinyalemen tandatanda lain gerakan bawah tanah itu dimulai dengan munculnya radikalisme lewat Partai Rakyat Demokratik (PRD) yang dipimpin Budiman Sujatmiko dengan Solidaritas Mahasiswa Indonesia Untuk Demokrasi (SMID) sebagai organisasi onderbounnyy. Dalam Anggatan Dasar Partainya, PRD tidak mengazaskan perjuangannya kepada Pancasila maupun agama tertentu, melainkan yang sifatnya kerakyatan semesta dan demokrasi. ${ }^{13}$ Di samping juga ada (pergakuan terselubung) yang dinyatakan oleh salah satu pimpinan Komite Pimpinan Pusat PRD, Mirah Mahardika dalam wawancara dengan Wikimedia:

Akhir-akhir ini terdengar berita yang menjadi hangat di antara para aktivis prodemokrasi, yaitu rencana kediktatoran Orde Baru yang akan menyatakan PRD dan beberapa organisasi lain sebagai OT (Organisasi Terlarang). Seperti yang diberitakan SiaR tanggal 27 September 1997, ada 32 organisasi yang tergabung dalam aliansi besar Majelis Rakyat Indonesia (MARD) yang akan dinyatakan sebagai OT. Rencana pengumuman OT itu, menurut informasi yang kami dapat, adalah tepat pada 30 September nanti, yaitu tepat peringatan G.30.S. PKI. Sebab, organisasi yang dinyatakan OT pastilah akan diidentikkan dengan Partai Komunis Indonesia (PKT). ${ }^{14}$

Demikian pula dalam pernyataan sikap menyambut ulang tahun ke-52 revolusi 17 Agustus 1945, PRD menegaskan:

Hari ini, tanggal 17 Agustus 1997 merupakan hari yang sangat penting bagi perjalanan sejarah Bangsa Indonesia dalam menuju kebebasan, karena hari ini genap 52 tahun usia revolusi kemerdekaan bangsa kita. Usaha merebut kemerdekaan telah dilakukan dengan penuh pengorbanan oleh para pahlawan kita, khususnya oleh kaum revolusioner. Perjuangan membebaskan diri dari penjajahan kolonialisme-imperialisme telah dilakukan secara bahu-membahu oleh semua kelompok dan partai politik di negeri ini, baik oleh kaum nasionalis, kaum komunis, kaum Islam, kaum Katholik, kaum Kristen, kaum sosial demokratik, dan sebagainya. ${ }^{15}$

${ }^{12}$ Anonymous, dikutip dari http:// wikimedia foundation.org/ diunduh 18 April 2012.

${ }^{13}$ Anonymous, dikutip dari www.prd.4-ail.org diunduh 18 April 2012.

${ }^{14}$ Anonymous, dikutip dari http//wikimediafoundation.org//, diunduh 18 April 2012. ${ }^{15} \mathrm{Ibid}$. 
Bukti lain berupa pemutarbalikan fakta sejarah. Yakni tuduhan tentang dalang pemberontakan PKI 1948 dan 1965 di KOMNAS HAM (terutama oleh ketuanya Abdul Halim Garuda Nusantara) merupakan labeling politik yang memojokkan PKI. Padahal G 30 S PKI terkait dengan rencana dan masalah internal TNI $A D .{ }^{16}$ Upaya lain berupa usulan sebagian guru di Jawa Tengah tahun 1999 agar Mendiknas mencabut pernyataan keterlibatan PKI tersebut. Pada tahun 2005 Mendiknas dan Menko Kesra hampir memenuhi tuntutan itu. Akan tetapi hal itu tidak terjadi karena ada penolakan Tim 9 yang dipimpin $\mathrm{KH}$. Yusuf Hasyim. Demikian pula tuntutan oleh Tapol dan Napol kepada pemerintah untuk mencabut TAP MPRS XXV/1966 lewat LSM-LSM tahun 2003 tentang pelarangan komunisme di Indonesia. Akan tetapi semua itu ditentang oleh elemen masyarakat yang anti komunisme, seperti Front Anti Komunis Gabungan se-Jawa, Persatuan Masyarakat Anti Komunis Bandung/PERMAK, Front Anti Komunis Yogyakarta/FAKY, serta Masyarakat Anti Komunis dan CICS Jawa Timur. ${ }^{17}$

Fakta tersebut membuktikan bahwa idiologi dan gerakan komunisme yang dapat menghancurkan bangsa Indonesia ini masih ada. Lalu bagaimana langkah nyata untuk menangkal hal itu? tulisan berikut ini diajukan analisisnya. Pembahasan dimulai dari dasar pemikiran komunisme hingga menjadi idiologi dan getakan radikal. Kemudian dilanjutkan analisis mengenai konsep pendidikan sebagai langkah nyata untuk menangkal idiologi itu. Pertanyaanya, kenapa mesti pendidikan? Jawabannya pertama, karena melalui pendidikan bisa dilakukan perubahan dasar pemikiran dan idiologi dengan tetap menjunjung tinggi nilai-nilai kemanusiaan dan moralitas tanpa dibarengi pelanggaran HAM, jika dibandingkan dengan cara lain: militer, hukum, ekonomi, dsb. Kedua, pendidikan pada hakekatnya berlangsung seumur hidup. Untuk itu jika dasar pemikitan telah tercerna oleh suatu generasi lewat pendidikan, maka yang bersangkutanlah yang melanjutkannya melalui self-education dalam rentang kehidupannya.

16 Firos Fauzan, Citil War Ala PKT 1965: Menyingkep Devan Revolusi PKI, Jakarta: Accelerate, 2011) Foundation, hal. i.

17 Ibid, hal. ii-iv. 


\section{B. Pembahasan}

Deskripsi tulisan ini dimulai dari, pertama, dasar pemikiran komunisme, meliputi: pemikiran Marxis-Leninis-Maois-PKI dan tahap kesadarannya jika ditinjau dengan teori tahap kesadaran Paulo Freire. Kedua, penemuan konsep pendidikan dengan dasar pemikiran komunis tersebut. Ketiga, pembahasan tentang langkah nyata pendidikan yang bisa menangkal idiologi komunis. Untuk itu perlu dibahas tentang Teori Kritis Jurgen Habermas sebagai. antitesa pemikitan dasar Marxis (sekaligus Leninis-Maois-PKI). Juga pemikiran dasar pendidikan Habermas yang dapat digunakan sebagai penangkal idiologi tersebut (PKI).

\section{Dasar Pemikiran Komunisme Marxis-Leninis-Maoi-PKI}

Berawal dari penyebaran dan pengokohan pemikiran Marxisme-ortodox yang berpijak pada penafsiran positivisme terhadap ajaran Marx, bahwa sistem kapitalisme akan segera hancur secara alamiah dan kemudian disusul serta diganti dengan munculnya sistem sosialisme. Ini didasarkan pada hipotesa Marx dalam Das Kapital, yang menyatakan bahwa dengan semakin berkembangnya kapitalisme berarti semakin terkonsentrasikannya modal pada kaum kapital dari kaum proletar. Hal itu menyebabkan bertambahnya kelas proletar, secara otomatis kekuasaan akan beralih ke kelompok proletar. Namun dalam perjalananya realitas seperti itu tidak pernah ada. Bahkan oleh Eduard Bernstein (seorang cendikiawan Marxis), dinyatakan bahwa asumsi itu tidak akan terjadi karena kaum 'kapitalis pandai menyesuaikan diri dengan kondisi yang berkembang daiam masyarakat. Pendapat ini dianggap sebagai Revisionisme oleh pengikut Marxisme-ortodoks (termasuk Lenin) dan ditentangnya. Selanjutnya pemikitan kritis Marx, oleh kaum ortodoks tersebut, diselewengkan dan dibekukan dalam bentuk keyakinan Idiologis. Ini terbukti dengan terbentuknya aliansi buruh sedunia dengan poros pengendalinya Uni Soviyet, yang justru menimbulkan tindakan anti demokrasi. Ini sesungguhnya berlawanan dengan 
gagasan awal Marx yang ingín memerdekakan masyarakat dari belenggu kaum Borjuis/Kpitalis lewat sosialismenya, dalam bentuk masyarakat komunal/komunis. ${ }^{18}$ -

Kemudian Lenin, dengan Marxisme-ortodoksnya, lebih menekankan pada determinisme ekonomi sebagaimana Marx itu sendiri dan itu menjadi dasar dialektika materialismenya. Artinya sejarah ditentukan serta diawali oleh kiprah (pekerjaan/ produksi) manusia yang paling dasar seperti memenuhi kebutuban makan, minum, dan berpakaian, sebelum melakukan tindakan lain; bemegara, berpolitik, seni, hukum, dsb. Dengan kata lain sejarah dimengerti atas dasar dialektika ekonomi dengan struktur kelas sosial. Jika ini terjadi maka muncul kelas sosial berdasar hak milik dan itu akan menghambat perkembangan, maka akhirnya memunculkan perubahan sosial yang itu sifatnya pasti revolusioner.

Di samping itu juga hal tersebut melahirkan bentuk masyarakat baru tanpa kelas. Akan tetapi gagasan Marx tersebut ditolak ketika Lenin menyadari bahwa revolusi tidak akan muncul dengan sendirinya sebagaimana teori Marx; yang menganggap revolusi akan terjadi sebagai akibat melemahnya kapitalisme secara alamiah (akibat perluasan pasar, produksi gila-gilaan yang berujung pada jatuhnya harga). Lenin justru melihat revolusi bisa terjadi kalau partai mau melakukan revolusi. ${ }^{19}$

Untuk kepentingan itu maka perlu kekuatan yang tersatukan dan terpusat serta dikuasai oleh negara. Artinya periu kapitalisme negara, yakni negara mengadministrasi hak milik. Itulah pembelokan Marxisme menjadi sebuah idiologi oleh Lenin dan yang sekaligus membedakannya dengan Marx. ${ }^{20}$ Padahal - bagi Marx, dalam komunisme tidak ada kelas sosial, tidak ada hak milik pribadi, alat produksi diurus langsung oleh yang bekerja di situ. Jadi negara bukan sebagai alat untuk tindakan totaliter, sebab dalam totalitarianisme perbedaan kelas muncul kembali dan dalam bentuk kediktatoran oleh segelintir kaum elit. Negara adalah untuk kesejahteraan bersama, oleh karena itu yang tepat adalah berupa sosialisme negara dalam proletariat. Negara boleh ada hanya sementara

18Ftanz Magnis Suseno, Pemikiran Karl Marx: Dari Sosialisme Utopis Ke Perselisiban Revisionisme, (Jakarta! Gramedia, 2000), hal. 5. $172-173$

${ }^{19}$ Rodee, C.C. et.al., Pengantar IImu Politik (Jakarta: PT. Raja Grafindo Perkasa, 2000), hal. 
dalam rangka nasionalisasi. Ini ditujukan untuk menyingkirkan kapitalis. Jika mereka sudah tidak ada dan tidak menjadi ancaman, maka negara menjadi hilang dan masyarakat terbentuk secara komunal (komunis).

Selanjutnya Maoisme, merupakan Marxisme yang khas Mao Zedong. Dalam hal ini dialektika sejarah Marxis difahami sesuai kondisi riil masyarakat Cina. Ini merupakan wujud semangat nasionalismenya, walaupun tidak berarti sefaham dengan confusianisme. Jika Marxisme memandang revolusi akan berakhir setelah tercapainya masyạakat komunal; yang berarti munculnya sosialisme negara dalam proletariat, maka bagi Maoisme revolusi tidak akan berakhir. Negara juga harus -ada karena ia menjadi wadah bagi nasionalisme Cina, sehingga keberadaannya sangat bernilai. Jadi bukan seperti Lenin yang memandang negara hanya sebagai alat pengadministrasian kepentingan masyarakat komunal. ${ }^{21}$ Itulah wujud pembekuan pemikiran kritis Marx ke dalam idiologi dan langkah politis yang khas Cina. Pembekuan itu juga terlihat pada konsep politik Mao tentang "garis massa", yang kemudian dikenal dengan selogan "dari massa, untuk massa". Maksudnya bahwa kebijakan politik partai yang bagus jika gagasan itu secara mumi bersumber pada massa (petani dan pekerja), dengan selalu memperhitungkan kepentingan dan. keinginan mereka. Dengan kata lain implementasi kebijakan tersebut harus mendapat dukungan dari massa., ${ }^{22}$

Pernikitan dan tindakan Mao tersebut cukup moralis, sehingga dapat dikatakan bahwa gagasannya telah merubah teori "materialisme-dialektik" Marx, menjadi "moralisme-dialektik". Mao Zedong berpendapat bahwa dalam rangka transformasi masyarakat tradisional ke moderen yang khas Cina (berupa kemajuan industrialisasi) harus dibarengi dengan penanaman sosialisme sebagai landasan moralitas masyarakat. Jika hal itu tidak dilakukan maka tidak akan menjamin kelanggengan masyarakat baru yang diharapkannya. Strategi moralisme-dialektis tersebut menupakan program "Lompatan Jauh ke Depan" (the Great Leap Fonvard) yang dilakukan pada tahun 1958-1959. Ini dimaksudkan untuk

${ }^{21}$ F.M Suseno, Pemikiran Karl Marx: Dari Sosialisme Utopis Ke Perselisiban Revisionisme... hal. 170-171.

22 J.C.F., Wang, "Values of the Cultural Revolution" dalam Joumal of Communication, vol 27 , no. 3 (1970), hal, 55. 
menebus kesalahan strategi pertamanya. Yakni yang hanya menitik beratkan pada pembangunan industri semata. Tujuan strategi itu untuk mengubah Cina menjadi suatu negara sosialis industri yang modern secepat mungkin. Guna mewujudkan langkahnya secepat mungkin, maka pelaksanaannya boleh melompati. tahap-tahap normal pembangunan supaya memperpendek jalan menuju sosialisme. Terkait dengan itu pula maka kesadaran masyarakat harus dirubah menuju kesadaran sosialis yang kuat dan sekaligus diwujudkan dalam kehidupan sehari-hari. ${ }^{23}$

Kemudian bagaimana dasat pemikiran komunisme di Indonesia (PKI)? Tampak tidak jauh beda dengan yang dikembangkan oleh Lenin-dan Mao Zedong. Yaleni pemikiran kritis Marxis dibelokkan menjadi sebuah idiologi. Langkah politik untuk mewujudkan idiologi itu di tempuh dengan cara yang sangat radikal, menghalalkan segala cara serta keji, sebagaimana yang muncul dalam bentuk pemberontakan tahun 1926 di Sumatera Barat dan Jawa Barat, peristiwa Madiun 1948, dan G. 30 S. PKI 1965. Kesimpulan ini didasarkan pada data bahwa tidak ada pemikiran filosofis kritis-Marxisme yang khas Tan Malaka, Muso, D.N Aidit, dll, yang dikembangkan di Indonesia, selain hanya memanfaatkan idiologi Leninis-Maois yang sudah mendunia untuk kepentingan ambisi pribadinya.

\section{Tahap Kesadaran Masyarakat Yang Dibangun Marxisme}

Dari pembahasan di atas dapat difahami bahwa tahap kesadaran masyarakat yang dibangun oleh komunisme Marxis-Leninis-Maois-PKI ialah tingkat kesadaran sosialis. Akan tetapi implementasinya dalam bersosial, berpolitik, dan bernegara pada Manxisme Karl Marx, berbeda dengan ketiga penganutnya tersebut (Lenin, Mao Zedong, dan tokoh-tokoh PKI). Pada ketiganya sosialisme diwujudkan secara raditeal, totaliter, dan anarkbis. Padahal

${ }^{23}$ E. L, Wheelwright, \& Mc. Farlane, B. (ed.), The Chinese Road to Socidtism: Economics of the Cultural Revolution, (London: Penguin Books, 1973), hal, 80. 
langkah itu sangat ditentang oleh Karl Marx, sebagaimana kritiknya terhadap Mikhail Bakunin (hidup tahun 1814-1876) dari Rusia. ${ }^{24}$

Dengan meminjam teori Paulo Freire tentang tahap kesadaran masyarakat, maka dikatakannya ada tiga, yaitu semi-intransitif, transitif-naïf, dan transitif-kritis. ${ }^{25}$ Tahap semi-intransitif ditandai dengan dikuasainya manusia oleh mitos-mitos yang diciptakan olch kekuatan sosial. Sikap dan perilaku mereka tidak berdasar kemandirian, tetapi dikomando oleh suasana yang dibentuk oleh kelompok yang dipandang masyarakat mitis sebagai yang layak dipatuhi. Mereka hidup dalam kondisi tertindas, inferior, tidak percaya diri/rendah diri, dan suasana psikologis lain yang seperti itu. ${ }^{26}$

Kemudian tahap transitif-naif ialah kesadaran yang lebih melihat sisi manusia sebagai penyebab permasalahan hidup. Misal masalah etika, kreatifitas, dll., muncul oleh karena faktor manusianya sendiri yang memang pemalas, tidak punya semangat untuk bangkit dan merubah nasibnya, tidak punya semangat wirausaha, dsb. ${ }^{27}$

Berikutnya tahap transitif-kritis, yaitu kesadaran manusia yang melihat sumber permasalahan hidup lebih diakibatkan oleh struktur dan sistem; sosial, politik, ekonomi, dan budaya. Menurutnya hal itu terutama dimunculkan oleh kaum elit (Brazilia) yang berpandangan-borjuis serta kapitalis. Karena kondisi yang tidak human itulah menjadikan manusia sadar, dan kesadaran kritisnya itulah mengemuka dalam bentuk tindakan transformatif tethadap sistem dan struktur yang selama ini membelenggu kehidupan mereka. ${ }^{28}$

Berdasar pada data tentang tahap kesadaran yang dibangun marxisme Leninis-Maois-PKI dan teori tahap kesadaran Paulo Freire, dapat.dianalisis bahwa tahap kesadaran sosialisme yang radikal, totaliter, dan anarkbis marxisme

Nes:

${ }^{24}$ F.M Suseno, Pemikiran Karl Marx: Dari Sosialisme Utopis Ke Perselisitan Retisionisme ..., hal. $242-243$.

25 Paulo R.N Freire, Education for Critical Consciousness (Cambridge, USA: Masschusetts, 1973), hal. $3-20$.

\footnotetext{
26 Ibid, hal. 17.

${ }^{27}$ Ibid, hal. 18.

${ }^{28}$ Ibid, hal. $18-20$.
} 
tersebut termasuk dalam tahap kesadaran semi-intransitif dan transitif-naif. Penyamaan itu didasarkan pada kesamaan jenis perilaku mereka. Yakni mereka cenderung menyederhanakan persoalan dan berprilaku dan berprikehidupan dibawah standar manusia pada umumnya. Hal ini dapat dilihat dari tindakan mereka yang keji dan suka menghalalkan segala cara demi kepentingan diri dan kelompoknya. Di samping mereka sangat sektarian, dan merasa paling benar sendiri, sehingga jauh dari karakter yang selalu ingin melakukan investigasi dan dibarengi dengan penjelasan-penjelasan yang fungsional dan akurat. Pikiran mereka juga dipenuh dengan angan-angan kosong. Begitu pula kepribadiannya diwarnai oleh kemampuan berargumentasi yang sangat rapuh karena dasardasar logikanya yang tidak kokoh. Sehingga diskusi/perdebatan selalu diakhiri dengan ungkapan "pokok-e atau harus begini, begitu, menutup segala kemungkinan yang lebih terbuka, dsb." Jelas yang demikian adalah sikap menutup sendiri (exclusive) dan maunya menang sendiri. Juga ditopang dengan penjelasan-penjelasan yang bersifat magis dan mitis, seta karakter mereka yang emosional dan senang berpolemik daripada dialog/komunikasi.

\section{Konsep Dasar Pendidikan Komunisme}

Untuk menetapkan konsep dasar pendidikan komunisme, jika didasatkan analisis dari teori pendidikan Paulo Freire yang berdasar pada tahap kesadaran masyarakat yang telah dirumuskannya, yaitu semi-intransitif, transitif-naif, dan transitif-kritis. Langkahnya adalah dengan memperhatikan indikator-indikator yang ada pada tahap kesadaran komunisme-(Marxis-Leninis-Maois-PKI), kemudian ditafsirkan menurut kriteria teori pendidikan Paulo Freire dimaksud.

Ditilik dari dasar ontologi dan epistemologi, maka tampak bahwa bagi mereka yang. berkesadaran semi-intransitif dan transitif-naif, realitas difahami secata empiris (sebagaimana yang tampak). Namun pada saat yang sama realitas dipandang sebagai sesuatu yang lain secara kontradiktif. Ini disebabkan bukan oleh ketidaktahuan mereka, melainkan justru karena kesengajaan (pada dasarnya tahu tetapi kemudian sengaja pura-pura tidak tahu/membodoh). Jadi subjek mendominasi objek dalam rangka rekayasa atau memutarbalikkan fakta. Secara onologis dan epistemologis, mestinya mereka termasuk berfaham dualisme, tetapi 
dalam prakteknya mereka memandang realitas dengan sebelah mata; yang empirik dan rasional / dunia dan akherat, ada, tetapi rasional dan atau akherat dibekukan (sengaja tidak mau tahu/pokok-e) demi mengutamakan dunia/ jasmani/empirik.

Dengan pandangan dunia seperti itu maka belajar merupakan pengukuban / absolutisme yang normatif atas pengalaman. Demikianlah teori belajar yang berkembang pada masyarakat komunis yang berkesadaran semi-intransitif dan transitif-naif. Artinya pengalaman disesuaikan dan diukur dengan norma yang dipandang benar (subjektif). Ini sesuai dengan kepribadian mereka serta jenis penalaran yang dipeganginya selama ini, yaitu deduktif. Dengan demikian pengalaman bukan hal yang pokok melainkan sekedar pelengkap. Sebaliknya subjek / native sangat menentukan dalam perolehan pengetahuan.

Akan tetapi karena subjek lebih mendominasi dan justru cenderung mengutamakan pengalaman / konkrit, maka terjadi pemutarbalikan kenyataan; yang tidak utama menjadi utama secara sengaja / membodoh, dan berkelanjutan / dilestarikan. Dari itu pula maka sikap stagnan / statis (sama dengan pasrab) yang berkembang pada masyarakat tersebut. Hal itu berpengaruh pada penerapan metode belajar yang bersifat imitatif dan tidak mampu mengembangkan dinamika berpfikimya secara realistis yang ilmiah, melainkan lebih bersifat kontradiktif. Dari itu pula tentunya metode pembelajarannya pun bercorak instruksional dan berbentuk indoktrinasi. Dari sifatnya yang stagnan dan statis itu pula, isi dan lingkup pembahasan materinyapun hanya melingkar pada persoalan yang itu-itu saja; rutin, mengulang-ulang, tidak berkembang, tidak actual / tidak up to date (kadaluwarsa), dan tidak fungsional.

Atas pertimbangan itu maka dapat difahami bahwa pada hakekatnya pendidikan mereka bisa diartikan sebagai proses pelimpaban materi / kebudayaan dari suatu generasi kepada genarasi lainnya yang coraknya monoton. Hasil edukasi pada tahap semi-intransitif dan transitif-naif (sama dengan kesadaran sosialis LeninisMaois-PKD), dan padanya tercermin suatu karakter sosialis yang radikal, totaliter, dan anarkbis, difahami oleh Paulo Freire mengandung manipulasi. ${ }^{29}$ Artinya pendidikan berlangsung bukan berdasar hubungan manusia dengan dunianya secara objektif.

${ }^{29}$ Ibid., hal. 148. 
Akan tetapi proses itu merampas hak kemanusiaan atau kebebasannya, karena, dengan meminjam istilah Malcolm Knowles yang dilansir Departemen Kesejahteraan Pendidikan dan Kesehatan Amerika Serikat, ${ }^{30}$ tentang perbedaan antara paedagogy dengan andragogy, pendekatan pendidikannya bersifat paedagogis. Maksudnya, dalam pendidikan tersebut pendidik dan terdidik didudukkan atas dasar hubungan dialektis yang tidak seimbang. Mereka laksana penindas dan yang tertindas, pemerintah dan yang diperintah, guru dan murid atau yang memberi dan yang diberi. Jadi guru sebagai subjek pendidikan (instruktur), sedangkan murid sebagai objek pendidikan(yang menerima instruksi).

\section{Langkah Edukatif Menangkal Gerakan PKI Anti Hak Asasi Manusia}

Dalam tulisan ini Teori Kritis Jürgen Habermas sebagai konsep dapat dijadikan langkah nyata untuk menangkal dasar pemikiran komunisme yang anti hak asasi manusia. Alasannya, teori Habermas merupakan antitesa pemikiran dasar Marxis (sekaligus Leninis-Maois-PKD). Di samping terkandung juga di dalamnya pemikiran dasar pendidikannya yang dapat digunakan sebagai penangkal idiologi tersebut (PKI). Untuk itu di sini akan dibahas dua hal, yaitu Teori Kritis dan Dasar Pendidikan yang dikembangkan Habermas.

\section{a. Teori Kritis Jürgen Habermas}

Bagi Habermas, teori Marx merupakan suatu filsafat sejarah, dan teori ini dapat diberi suatu dasar empiris. Artinya bisa digunakan kontrol empiris untuk menentukan syarat-syarat objektif yang berlaku bagi berlangsungnya revolusi. Dari itu filsafat sejarahnya dengan tujuan praxis tidak pernah memiliki suatu kepastian meta-empiris, tetapi harus diberi fondamen yang kokoh dalam verifikasi empiris. Juga teori sosial Marx berdimensi dua yaitu tindakan instrimental dan tindakan komunikatif / reflektif.

Tindakan instrumental ialah tindakan pekerjaan atau produksi, yakni alat-alat kerja, teknologi, serta ketrampilan para pekerja. Manusia berhubungan dengan alam melalui pekerjaan. Untuk itu manusia menciptakan alat-alatnya, mengembangkan kekuatan-kekuatan produktif baru, sehingga dengan cara

${ }^{30}$ Malcolm Knowles, A Trainers Guide to Andragogy, Revised Edition, (Washington D.C: US Departement of Health, Education and Welfare, 1973). 
tersebut manusia merefleksikan diri dan membebaskanya dari kendala-kendala alam. Teori tersebut berdampak pada manusia yang menjadikan diri, pertama, sebagai proses perwujudan diri melalui kegiatan produksi. Kedua, sebagai proses pendidikan melalui tindakan revolusioner.

Teori Marx tersebut, bagi Habermas, hanya menekankan pada dimerisi pertama yaitu pekerjaan. Akibatnya dimensi kedua menjadi terabaikan, yang sebenarnya hal itu merupakan syarat kemungkinan emansipasi dari hubunganhubungan kekuasaan karena membuka kedok idiologi-idiologi yang ada yakni dimensi komunikasi atau refleksi.

Dengan refleksi manusia dapat membuka kedok idiologi yang menutupi struktur kekuasaan. Sementara dimensi pertama hanya mereduksi manusia pada pekerjaan yang hanya menggunakan tindakan searah dan tidak bersifat reflektif. Di lain pihak, Marx memahami emansipasi sebagai tujuan yang dapat diusahakan secara objektif. Yaitu semata-mata melalui perkembangan tanpa melibatkan komunikasi dan interaksi. Juga Marx memandang pembebasan manusia dianggap sebagai masalah teknologi. Dengan pandangan hukum objektif perkembangan sejarah itulah faham Marxis menjadi saintistik. Yaitu suatu proses yang bercorak linear dan memandang ilmu tentang manusia sepadan dengan ilmu alam. ${ }^{31}$

\section{b. Teori Sosial Emansipatoris Jürgen Habermas}

Teori sosial kritis emansipatoris Habermars bercorak praxis, dan ia berpijak pada teori Karl Marx yang dikritisi dan dikembangkan. Pengembangan dimulai dengan, pertama, berdasar pada konsepnya tentang praxis, menyegarkan kembali pemikiran-pemikitan Marxis yang menyangkut dua pokok masalah yaitu hubungan teori dan praxis maupun materialisme sejarah. Usaha mencari pertalian teori. dan praxis ditempuhnya dengan jalan konsensus dan komunikasi. Kedua, berdasar pada konsep praxis itu pula ia bermaksud memecahkan jalan buntu yang dihadapi generasi I Teori Kritis.

Penjelasan tersebut tampak pada usahanya merumuskan kembali konsep rasionalisasi. Jika menurut Marx perkembangan masyarakat/manusia ditentukan oleh keadaan masyarakat/manusia yạng senyatanya (proses kerja/tindakan

${ }^{31}$ Habermas, Jürgen, Teon Tindakan Konunikatif II: Kritik Atas Rasio Fungsional, terj: Nurhadi (Yogyakarta: Kreasi Wacana, 2007), hal. 450 - 451. 
rasional bertujuan), maka bagi Habermas hal itu sekaligus juga ditentukan oleh interaksi/komunikasi (tindakan komunikasi). Di sini Marx tampak lebih menekankan dimensi epistemologis pada kerja, bukan pada komunikasi. Padahal keduanya merupakan tindakan dasar masyarakat/manusia. Pada tindakan rasional bertujuan menunjukan tindakan dasar hubungan manusia dengan alam, dan sifatnya satu arah (subjek ke objek / monolog). Sedangkan tindakan komunikatif, mencerminkan tindakan dasar hubungan manusia dengan sesamanya; dua arah timbal-balik/dialog.

Akan tetapi pada kenyataannya, seperti yang difahaminya pada masyarakat Barat, tampak bahwa konsep rasionalisasi yang semestinya menunjukkan berjalanya tindakan rasional berutujuan dan tindakan komunikasi; hubungan teori dan praxis, bersifat sejalan dan berbarengan, malah sebaliknya menjadi timpang. Mereka lebih menekankan pada dimensi kerja. Bersamaan dengan itu pula muncul sistem kapitalisme; yang ditopang teknologi dan sistem mekanik. Ini menyebabkan tindakan rasional bertujuan pada masyarakat tradisional, yang dijaga oleh legitimasi tradisi kebudayaan (inilah kerangka kerja institusional tradisional/dunia kehidupan sosial budaya yang menjamin berkembangnya interaksi/komunikast), menyebabkan penekanan lebih tertuju pada tindakan rasional bertujuan (kerja/produksi). Ini artinya masyarakat kehilangan pemahaman-dirinya yang bersumber pada tindakan komunikatif (berbentuk interaksi sosial atas dasar pemahaman dirinya sndiri), diganti dengan model pamahaman/ pengetahuan ilmiah atau saintis/mekanis.

Di sinilah terjadi reifikas-diri (pembendaan-diri) manusia ke dalam kategori tindakan rasional bertujuan. Dengan demikian kesadaran manusia yang terbangun adalah kesadaran teknokrasi; terarah, terkendali bumanitasnya, dan berwatak idiologis. Pada kesadaran yang seperti ini, kata Habermas, masyarakat telah kehilangan dimensi etisnya, dan jelas hal itu merupakan desakan dari atas, bukan berkembang dari bawah/budaya ${ }^{32}$

Melihat kenyataan di atas kemudian ia berupaya merumuskan suatu konsep rasionalisasi yang wajar, yang disebutnya dengan interaksi sosial emansipatoris, berdasar tindakan komunikatif. Rasionalisasi yang dimaksudkanya ialah berkenaan

32 Jürgen, Habermas, Towvard a Rationd Society, (London: Hoinemann, 1971), hal. 93 - 122. 
dengan perkembangan masyarakat secara seimbang. Hal itu menyangkut tiga hal, yaitu rasionalisasi teknis/dimensi kerja, rasionalisasi praxis/dimensi interaksi atau komunikasi, dan rasionalisasi sistem/dimensi kekuasaan. ${ }^{33}$ Makna konsep itu ialah bahwa perkembangan masyarakat/manusia hendaknya terarah kepada bentuk hubungan-hubungan kerja, komınikasi, dan kekuasaan. Dengan rasionalisasi ketiganya berarti mereka dapat sekaligus memperluas penguasaan teknis terhadap proses dunia eksternal masyarakat/manusia, mampu mengkondisikan situasi komunikasi yang bebas serta buman, dan akhirnya bisa menetapkan tujuan teknis serta praxis diri mereka secara sempurna. Melalui ketiganya, bagi Habermas, perkembangan màsyarakat/manusia bisa lebih buman (sesuai dirinya), tanpa terkendala/terjebak ke dalam ideologi.

\section{c. Pemikiran Pendidikan Habermas: sebagai penangkal untuk komunisme/PKI yang anti hak asasi manusia}

Pemikiran sosial kritis emansipatoris Habermas tersebut tentu berdampak pada konsep dasar pendidikanya. Bagi Keith Morrison, pengaruh pemikiran itu terhadap pendidikanya berupa konsep dasar (teori) pendidikan yang disebutnya . "Partisipan Potensial": Terkait dengan hal itu maka akan penulis jelaskan konsepnya tentang manusia (subjek pendidikanya), kurikulum, serta metode pembelajaranya. Pembahasan dicukupkan pada tiga hal tersebut, sebab padanya sudah termuat substansi dari konsep pendidikanya.

Konsep manusia menurut Habermas sangat bertolak belakang dengan Marxis-Leninis-Maois-PKI. Pada keempat pemikiran yang terakhir, manusia adalah sebagai pribadi yang berkesadaran semi-intransitif dan transitif-naijf sebagaimana telah dikemuakan dalam uraian terdahulu. Ini kemudian betdampak pada munculnya tatanan kehidupan masyarakat/manusia yang sosialis, namun radikal,totaliter, dan diktator proletariat (idiologis). Sebaliknya bagi Habermas, manusia yang digagasnya ialah yang sosialis-kritis-emansipatoris. Yakni manusia yang dengan kesadaranya dapat memperluas penguasaan teknis terhadap proses dunia eksternalnya, dan mampu mengkondisikan situasi

${ }^{33} \mathrm{JR}$ Sensat, Habemas and Marxism, (London: Sage Publication, 1979), hal. $42-43$.

${ }^{34}$ Keith Morrison, "Jürgen Habermas", dalam Joy A. Palmer (ed.) 50 Pemikiran Pendidikan: Dari Piaget Sampai Masa Sekarang (Yogyakarta: Jendela, 2003), hal, 382. 
komunikasi yang bebas dan buman. Juga bisa menetapkan tujuan teknis serta praxis dirinya secara sempurna. Dengan ketiganya, bagi Habermas, dapat menjadikkan perkembangan manusia lebih buman (sesuai dirinya), tanpa terkendala/terjebak ke dalam idiologi. Dengan kata lain Habermas bertujuan melakukan konsensus dan komunikasi terhadap tiga kepentingan kognitif masyarakat/manusia, yaitu teknis, praxis, dan emansipatoris. Ini dapat memunculkan masyarakat/manusia yang mampu mengelola dunia eksternalnya dengan nuansa pemahaman yang mendalam (dengan bermeneutik dan verstebent) terhadap realitas kehidupanya, serta dalam tata cara hubungan yang dialogis, setara, komunikatif, dan egaliter. ${ }^{35}$.

Untuk mendukung capaian karakter manusia seperti itu, maka rancangan kurikulumnya harus memuat materi pembelajaran yang mampu menumbuhkan potensi yang terkait dengan ketiga kepentingan kognitif tersebut; teknis, praxis, dan emansipatoris. Contohnya ialah materi pembelajaran tentang sadar budaya, kajian sosial, sadar lingkungan, multikulturalisme, dsb. ${ }^{36}$

Adapun metode pembelajaranya ialah dengan model riset-aksi / teoritis-praxis. Di sini ketiga kepentingan kognitif; teknis, praxis, dan emansipatoris, dapat termanifestasikan apabila dikemas dalam delapan prinsip metode pembelajaran. Metode tersebut tercakup dalam kegiatan yang bentuk kooperatif dan kolaboratif, diskusi, belajar mandiri, eksplorasi lingkungan, problem soling, orasi dan seminar agar terdidik mahir berbicara, reflektif/perenungan, serta kritis dan transformatif.

Melalui tiga konsep dasar pendidikanya itu; konsep tentang manusia, kurikulum, dan metode pembelajaran, maka realisasi teori pendidikan partisipan potensial yang digagasnya dapat terwujud. Sebab seluruh potensi. kedirian masyarakat/manusia berupa tiga kepentingan kognitif masyarakat/manusia, yaitu teknis (kemampu mengelola dunia ekstermalnya dengan nuansa pemahaman yang mendalam/bermeneutik dan verstehen terhadap realitas kehidupanya), praxis (kemampuan pengelolaan hubungan yang dialogis), dan emansipatoris (kemampuan mengkondisikan situasi komunikatif yang bebas dan egaliter, dapat tumbuh sesuai kemanusiaanya yang etis.

\footnotetext{
35 Ibid, hal. 386.

36 Ibid., hal. 387.
} 


\section{Penutup}

Sebagai akhir dari deskripsi, analisis dan diskusi dari keseluruhan tulisan ini dapat dikemukakan kesimpulan-kesimpulan sebagai berikut:

1. Bahwa bangsa Indonesia yang berdasar Pancasila harus terbebas dari Marxis-Leninis-Maois dan PKI. Masyarakat Pancasilais adalah yang beriman, bertaqwa, dan bermotal, bermartabat dan sopan-santun, yang menjunjung tinggi Multikulturalisme, yang bijaksana demokratis, komunikatif, dan dialogis, serta setara/egaliter.

2. Bahwa kepribadian tersebut sangat luhur, karena mencerminkan manusia yang seutuhnya, dan berbudaya sesuai realitas kehidupanya. Masyarakat Indonesia tersebut jauh dari sosialisme yang radikal, totaliter, dan diktator proletariat. Dengan demikian, mereka bukan kapitalis, liberal, dan saintistik.

3. Bahwa seluruh karakter terakhir tersebut, bagi Habermas, terbentuk atas dasar penekanannya pada konsep rasionalisasi yang timpang. Yakni partisipan potensial yang dimiliki masyarakat/manusia (berupa tindakan rasional bertujuan dan tindakan komunikast) yang seharusnya terbina secara seimbang, ternyata dalam prakteknya penekanan hanya tertuju pada tindakan rasional bertujuan/tindakan instrumental.

4. Bahwa Jangkah nyata untuk menangkal hal tersebut ialah dengan kritik idiologi. Yakni suatu ànalisis dalam rangka menemukan sisi kelemahan teori Marxis, terutama pembelokanya kearah idiologis oleh kaum MarxisLeninis-Maois dan PKI. Juga secara edukatif harus dirancang suatu tujuan pendidikan yang mampu mewujudkan masyarakat/manusia yang bisa mengembangkan tiga kepentingan kognitif; teknis, praxis, dan emansipatoris. Kemudian perlu disiapkan kurikulum yang mendukung pencapaian tujuan tersebut, seperti materi pembelajaran tentang sadar budaya, kajian sosial, sadar lingkungan, multikulturalisme, dsb. Selanjutnya materi.itu harus dikemas dengan metode pembelajaran yang berbentuk riset-aksi /teoritis-praxis. 


\section{DAFTAR PUSTAKA}

Fauzan, Firos. 2011. Civil War Ala PKI 1965: Menyingkap Dewan Revolusi PKI. Jakarta: Accelerate Foundation.

Freire, Paulo. 1973. Education for Critical Consciousness. The English-language edition for it was prepared in association with center for the Study of Development and Social Change Cambridge USA, Masschusetts.

Habermas, Jürgen. 1971. Toward a Rational Society. London: Hoinemann.

Habermas, Jürgen. 2007. Teori Tindakan Komunikatif II: Kritik atas Rasio Fungsional. Terj: Nurhadi, Yogyakarta: Kreasi Wacana..

Knowles, Malcolm. 1973. A Trainers Guide to Andragogy. Revised Edition. Washington D.C, US Departement of Health, Education and Welfare.

Legge, John D.. 1985. Soekamo: Sebuab Biografi Politik. Terj: oleh Tim PSH. Jakarta: Sinar Harapan.

Magnis Suseno, Franz. 2000. Pemikiran Karl Marx: Dari Sasialisme Utopis ke Perselisibian Revisionisme. Jakarta: Gramedia.

Mirah Mahardika. 1997. PRD Tak Gentar Dinyatakan "OT", http//wikimediafoundation.org// diunduh 18 April 2012.

Morrison, Keith. 2003. "Jürgen Habermas", dalam Joy A. Palmer (ed.) 50 Pemikiran Pendidikan: Dari Piaget Sampai Masa Sekarang. Yogyakarta: Jendela.

Nasution, A.H.. 1989. Memenubi Panggilan Tugas: Jilid 5 Kenangan Orde Lama. Jakarta: CV. Haji Masagung.

PRD.. 1994. Anggaran Dasar Partai Rakyat Demokratik, www.prd.4-all.org diunduh 18 April 2012.

Rene Goldman. 1968. "Mao, Maoism and Mao-logy" dalam Joumal of Pacific Affairs. Vol. 41, No. 4, hal. 566.

Rodee, C.C. et.al. 2000. Pengantar Ilmu Politik. Jakarta: PT. Raja Grafindo Perkasa.

Sensat, JR. 1979. Habermas and Marxism. London: Sage Publication. 
Soerojo, Soegiarto. 1988. Siapa Menabur Angin Akan Menuai Badai: G 30 S PKI dan Peran Bung Kamo. Jakarta: Intermasa.

Wang, J.C.F..1976. "Values of the Cultural Revolution" dalam Joumal of Communication, vol. 27, no. 3, hal. 55.

Wheelwright, E. L., Mc. Farlane, B. (ed.). 1973. The Chinese Road to Socialism: Economics of the Cultural Revolution. London: Penguin Books. 